Paper presented at the $2^{\text {nd }}$ Latin American Symposium of Cnidarians (XVIII COLACMAR)

\title{
Species delimitation in sea anemones (Anthozoa: Actiniaria): From traditional taxonomy to integrative approaches
}

\author{
Carlos A. Spano ${ }^{1}$, Cristian B. Canales-Aguirre ${ }^{2,3}$, Selim S. Musleh ${ }^{3,4}$, \\ Vreni Häussermann ${ }^{5,6}$, Daniel Gomez-Uchida ${ }^{3,4}$
}

1 Ecotecnos S. A., Limache 3405, Of 31, Edificio Reitz, Viña del Mar, Chile

2 Centro i mar, Universidad de Los Lagos, Camino a Chinquihue km. 6, Puerto Montt, Chile

3 Genomics in Ecology, Evolution, and Conservation Laboratory, Facultad de Ciencias Naturales y Oceanográficas, Universidad de Concepción, P.O. Box 160-C, Concepción, Chile.

$4 \quad$ Nucleo Milenio de Salmonidos Invasores (INVASAL), Concepción, Chile

$5 \quad$ Huinay Scientific Field Station, P.O. Box 462, Puerto Montt, Chile

6 Escuela de Ciencias del Mar, Pontificia Universidad Católica de Valparaíso, Avda. Brasil 2950, Valparaíso, Chile

\begin{abstract}
The present review provides an in-depth look into the complex topic of delimiting species in sea anemones. For most part of history this has been based on a small number of variable anatomic traits, many of which are used indistinctly across multiple taxonomic ranks. Early attempts to classify this group succeeded to comprise much of the diversity known to date, yet numerous taxa were mostly characterized by the lack of features rather than synapomorphies. Of the total number of species names within Actiniaria, about $77 \%$ are currently considered valid and more than half of them have several synonyms. Besides the nominal problem caused by large intraspecific variations and ambiguously described characters, genetic studies show that morphological convergences are also widespread among molecular phylogenies. On the contrary, spatial distribution has been emerging as a more reliable parameter to explain cryptic relationships among sea anemones. Integrative
\end{abstract}


approaches and genome-wide data have been especially helpful to unveil the mechanisms behind the speciation process, which is typically marked by large genetic differences among populations, even from neighbouring localities. This paper further discusses current gaps in our knowledge and offers some future directions on how to address the issue of species delimitation in the extremely polymorphic group of sea anemones.

Keywords Cnidaria - Hexacorallia - systematics - taxonomy - evolution

\section{Introduction}

The accelerating loss of biodiversity due to climate change and habitat fragmentation has been emphasizing the importance of species not only as a classification unit but as conservation target as well. Nevertheless, establishing how many species are inhabiting an area can be very challenging, especially in marine environments. One of the main reasons for this lies in the fact that many of the organisms that thrive in the ocean often present biological singularities that make them quite difficult to ascertain only in terms of taxonomic diversity. Clonality, for example, is far more frequent in soft-bodied, early-diverging animals than in most terrestrial taxa with poor regenerative capabilities (Hughes, 1987). In the same way, evolutionary processes, such as hybridization or phenotypic plasticity, may have a cumulative effect large enough to significantly distort diversity assessments, basically depending on how species are been delimited.

Sea anemones (order Actiniaria) are a good example to illustrate this point. While they represent a relatively small taxon within the phylum Cnidaria, its members can be found in benthic environments across all depths and latitudes worldwide (Daly et al., 2008). Species richness has been historically difficult to determine not only because of the lack of specialists, but also given the inherent complexities of actiniarians. In fact, even though the number of authors per publication has increased (Fautin, 2016), only a minor fraction of them appear recurrently in systematic studies. Much of the breakthroughs in this area, however, are being generated by young researchers who often explore the investigation of sea anemones because of their features as an enticing study model (e.g. Layden et al., 2016). To further motivate 
efforts in this line, here we review the topic from a historical perspective, focusing first on the milestones that shaped the current classification system of sea anemones. The species delimitation problem is specially discussed using Fautin (2013)'s database to characterize when and how species have been described. Finally, we will provide some future directions based on emerging patterns from recent studies using genetics and high-throughput sequencing technologies.

\section{Discovery and early classifications}

Old notes on sea anemones show that the stinging capability of cnidarians was the main reason why earliest zoologists decided to focus on these plant-like creatures. Aristotle, for instance, originally named them Acalephae or Cnidae (Gk. akalephe, nettle; cnidos, thread) based precisely on the sensation that these organisms produce upon contact. Moreover, he stated that even when their constitution may resemble plants, their ability to detach from the substrate, catch their food and react to stimuli indicate that they must possess some sort of animal nature within them. It was not until Lamarck (1801) that 'polyp' organisms were established as a class, assigning the sea anemone Actinia rufa to a minor section of members with radial naked body. He additionally coined the concept Radiata (Lat. radiatus, ray-like), which was later used by Cuvier (1817) as a much higher rank, expanding it to include all those animals previously known under the name Zoophyta (Gk. zōon, animal; phyton, plant). Furthermore, Cuvier restored the Aristotelian terminology to describe sea anemones as a base-fixed Acalephes, extracting them from the Polypi class which he used mostly for corals, hydroids, and bryozoans. Numerous investigators such as Johann Friedrich Eschscholtz, Michael Sars and George Johnston subsequently addressed the Radiata division, succeeding to broadly identify each one of their main zoological components. Among them, Frey and Leuckart (1847) first proposed the infra-kingdom Coelenterata (Gk. koilos, cavity; enteron, intestine), in which were also included several members of Spongiaria and Ctenophora. Berthold Hatschek extensively disclosed their anatomical differences and in 1888 he finally introduced the term Cnidaria, which shortly after came to comprise the class Anthozoa (Ehrenberg, 1834), as well as the ever-increasing group of skeleton-less, solitary polyps. 
Most descriptions of sea anemones were published between 1850 and 1950, many of which were carried out through large vessel-based expeditions (Fig. 1). The term Actiniaria (or Actinaria as originally spelled) was first introduced by James Dana in his Structure and Classification of Zoophytes (1846) as a suborder of Actinoidea (alternative group of Hydroidea) and included all Anthozoa but Alcyonaria (=Octocorallia). Its definition, however, changed over time due to continuous rearrangements of several members that currently belong to orders like Staurozoa and Antipatharia (e.g. Milne-Edwards and Haime, 1857; Haeckel, 1879). It was not until Richard Hertwig's reports that, based on the previous works of Gosse (1860), Verrill (1864) and Andres (1884), several conspicuous sea anemones were finally characterized under a common dichotomous key. While Hertwig (1882) only came to include thirteen families, this classification recognized major morphological features such as the pedal disc, acontia, and sphincter. Perhaps even more important, throughout his work he persistently emphasized the relevance of the internal anatomy to distinguish actiniarians, providing the groundwork for future taxa descriptions.

As new species were discovered, Hertwig's classification was eventually enhanced by Thomas Stephenson's papers. On his guide of the British Sea Anemones, Stephenson (1935) thoroughly leads the species identification from external features down to the types of cnidae the species possess (or cnidom); an aspect highly improved by the comprehensive studies of Robert Weill. While Weill (1934) distrusted the usefulness of cnidae for taxonomy, the growing shortage of diagnostic characteristics was enough to start requesting the measurements of these microscopic capsules in later descriptions. One of the main advocates to this claim was the Swedish naturalist Oskar Carlgren, whose work was greatly bolstered by Weill's terminology. By mid-20th century, Carlgren (1949) finally published A survey of the Ptychodactiaria, Corallimorpharia and Actiniaria, his prime work in the field of zoology and the result of over 50 years of studies in sea anemones. This paper had a massive impact on the taxonomic knowledge of Actiniaria, comprising a total of 38 families, 180 genera and being until today one of the most widely accepted classifications of the order. 


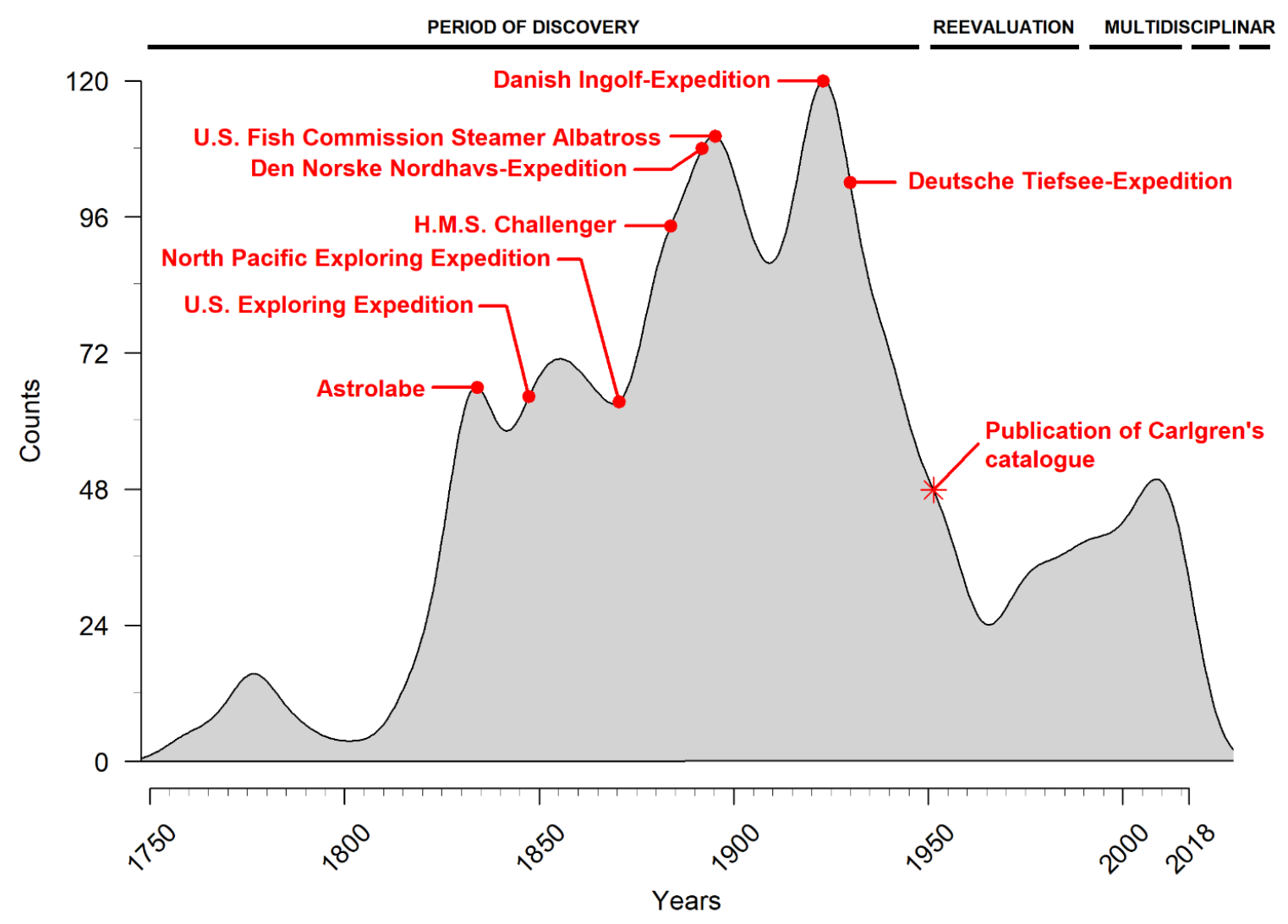

Figure 1. Kernel density estimation of actiniarians descriptions through time (data from Fautin, 2013). Oceanographic expeditions where more than 20 species were described are indicated next to the year of the publication of the expedition results. The year of the publication of a survey of the Ptychodactiaria, Corallimorpharia and Actiniaria by Carlgren (1949) is also signposted as the culmination milestone of the discovery period. The subsequent use of Carlgren's classification is compressed in a period of taxonomic reevaluation, in which the overall number of new species described is drastically reduced. Methodological advances in molecular techniques during the early 90's opened the possibility to use genetic tools to evaluate species hypothesis in complex taxa. This multidisciplinary trend has been growing ever since then and is showing no signs to change soon.

\section{Period of reevaluation: What is a species in sea anemones?}

During the second half of the 20th century, the composition and identity of several taxa became an increasingly complex issue to undertake, especially for larger families such as Actiniidae, Actinostolidae, and Sagartiidae. In fact, while the number of descriptions of new 
species decreased after Carlgren's catalogue, the number of re-descriptions drastically augmented over the last decades (e.g. Edmands and Fautin, 1991; Arellano and Fautin, 2001; Häussermann, 2004b; Spano et al., 2013). Of the 1427 names of actiniarian species that currently exist, 1101 are considered valid and nine are unavailable (Fautin, 2013, 2016). Moreover, about $60 \%$ of all valid species contains at least one synonymous name and over $10 \%$ are homonyms. Though these statistics are inevitably influenced by taxonomic reassignments and spelling errors in species names, a great portion of the synonyms can also be traced to morphological ambiguities, as many of the most recurrent species are often the ones that bear the largest number of synonyms (Fig. 2). Furthermore, the number of species considered valid is likely an overestimate because there is not enough evidence to prove how many species names actually refer to junior synonyms (Fautin, 2016).

Because they lack solid structures, taxonomy in Actiniaria had to rely on a handful of body attributes that vary in presence and form across groups. These features are used almost indistinctly from suborders to species diagnoses, showing a rather weak relationship between the taxonomic rank and the biological specificity of the trait (Fig. 3). Unlike what might be expected (i.e. the broader the group, the more 'evident' should be the differences that distinguish them), current classifications are heavily focused on the arrangement and morphology of the column, mesenteries, and muscles (see also Daly et al., 2015). Nevertheless, few of these characteristics are indeed consistently distinct among specimens. For example, both the number of tentacles and mesenteries are completed in cycles as the anemone grows; therefore, the variation range can only be estimated from the smallest and largest polyp found for the species (Stephenson, 1921). Likewise, body structures such as marginal projections not only become noticeable in adult individuals but also may vary due to environmental or ontogenetic factors (Francis, 1973; Bigger, 1980; Ayre and Grosberg, 1995). While the morphology of the musculature may seem less problematic, critically important features such as the sphincter muscle have not been exempted from controversies (England, 1987; Rodríguez and López-González, 2008; González-Muñoz et al., 2015). 


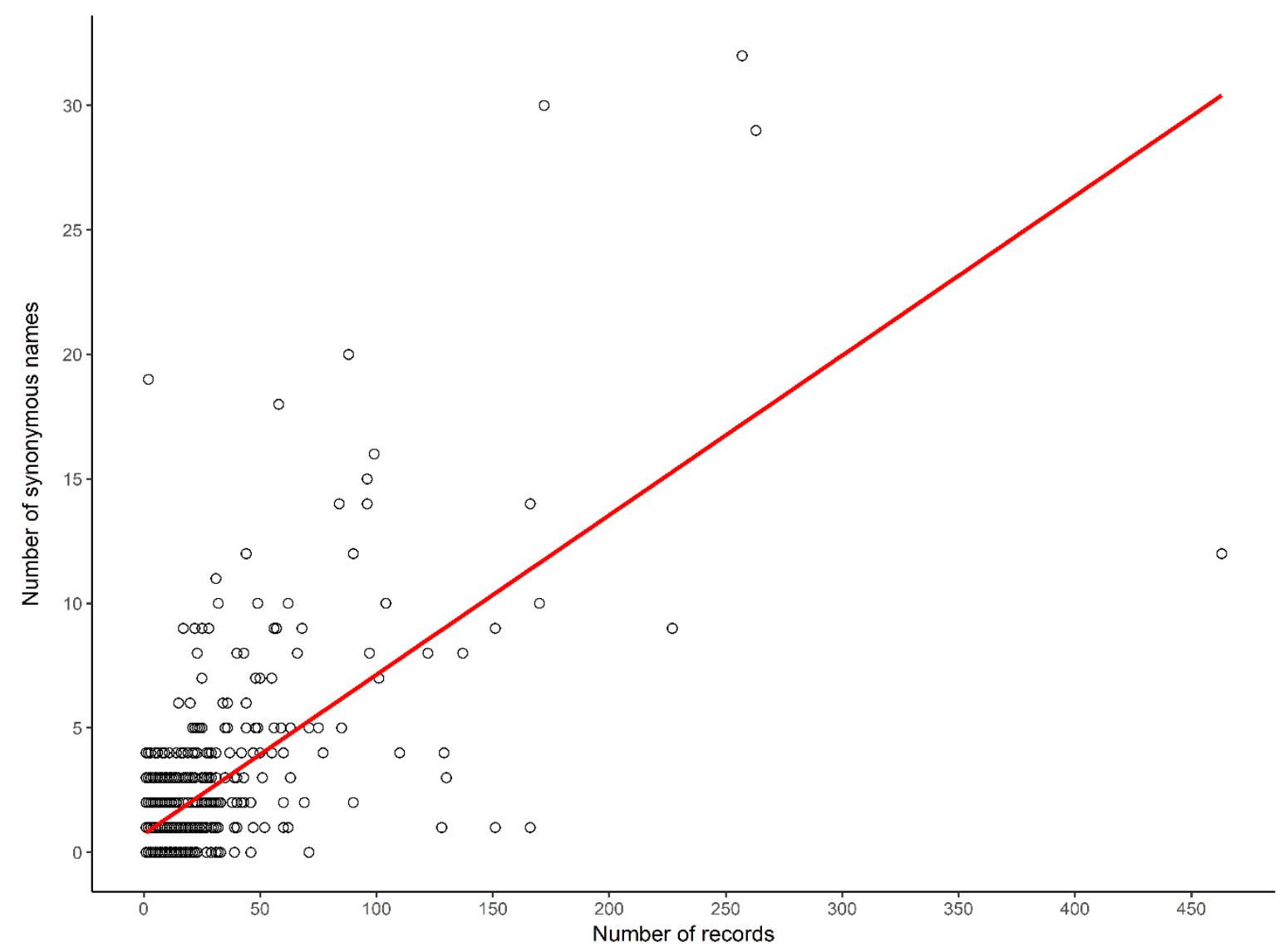

Figure 2. Relationship between the number of records for a species and its number of synonymous names. Approximately half of the species within Actiniaria has not been reported more than three times in the literature and about $60 \%$ has at least one synonymous name. Spearman's rank correlation coefficient indicates a moderate, but statistically significant correlation between these two variables (rho=0.438; $p$-value $<0.001)$.

The core issue for many of these examples is that it is still unclear which characteristics are derived from shared ancestry (i.e. homologies) and which ones are analogous responses from independent lineages. This pivotal distinction in systematics is particularly difficult to detect in sea anemones for two main reasons: incomplete descriptions, especially those prior to Carlgren (1949), and lack of knowledge about the structure and evolution of the diagnostic features presently used. Understanding how these traits evolve has become indispensable, more than ever because phylogenies are showing that both morphological convergences and character loss are recurrent phenomena in actiniarian systematics (Daly et al., 2008; Rodríguez et al., 2012; Rodríguez et al., 2014; Daly et al., 2017). Biological characters like 
the musculature, columnar outgrowths, and acontia are indeed fairly correlated to ecological shifts that have occurred more than once (e.g. adopting a burrowing habitat); therefore, they have seemingly been developed and lost several times throughout history (Rodríguez et al., 2012; Rodríguez et al., 2014). Some of these evolutionary changes could be even microanatomical and, based on recent observations, much more complex than have been appreciated up until now (Daly et al., 2017; Gusmão et al., 2018).

\section{The rising challenges of taxonomic description}

The diagnostic characterization of a species has typically been based on different combinations of some of the most variable features that distinguish sea anemones, such as the coloration pattern, the reproductive mode, and the cnidom. They have purposely been used given the wide range of character states that specimens may display in nature. Since the early 70', however, numerous studies have been pinpointing the existence of several secondary sources of phenotypic variation at smaller scales, for example, geographic distribution to different physiological races (Williams, 1973); body mass to cnidae measurements (Francis, 2004); habitat preferences to colour variability (Sebens and Paine, 1979; Häussermann, 2004b; Stoletzki and Schierwater, 2005); and photoperiod to breeding strategy (Schlesinger et al., 2010). Some of these differences are usually deemed as innate responses of the anemone to ecological factors like competition for space, food availability or water loss during low tide (e.g. Hart and Crowe, 1977). Stoletzki and Schierwater (2005), for instance, found a strong association between the colour and genetic variants of Condylactis gigantea and their capabilities to withstand UV radiation. The presence of mixed morphs may also suggests that some of these phenotypic differences are passed down to the offspring (e.g. Häussermann, 2004b), although is has not been tested for how many generations they are maintained, and whether they could eventually promote the formation of new species. 


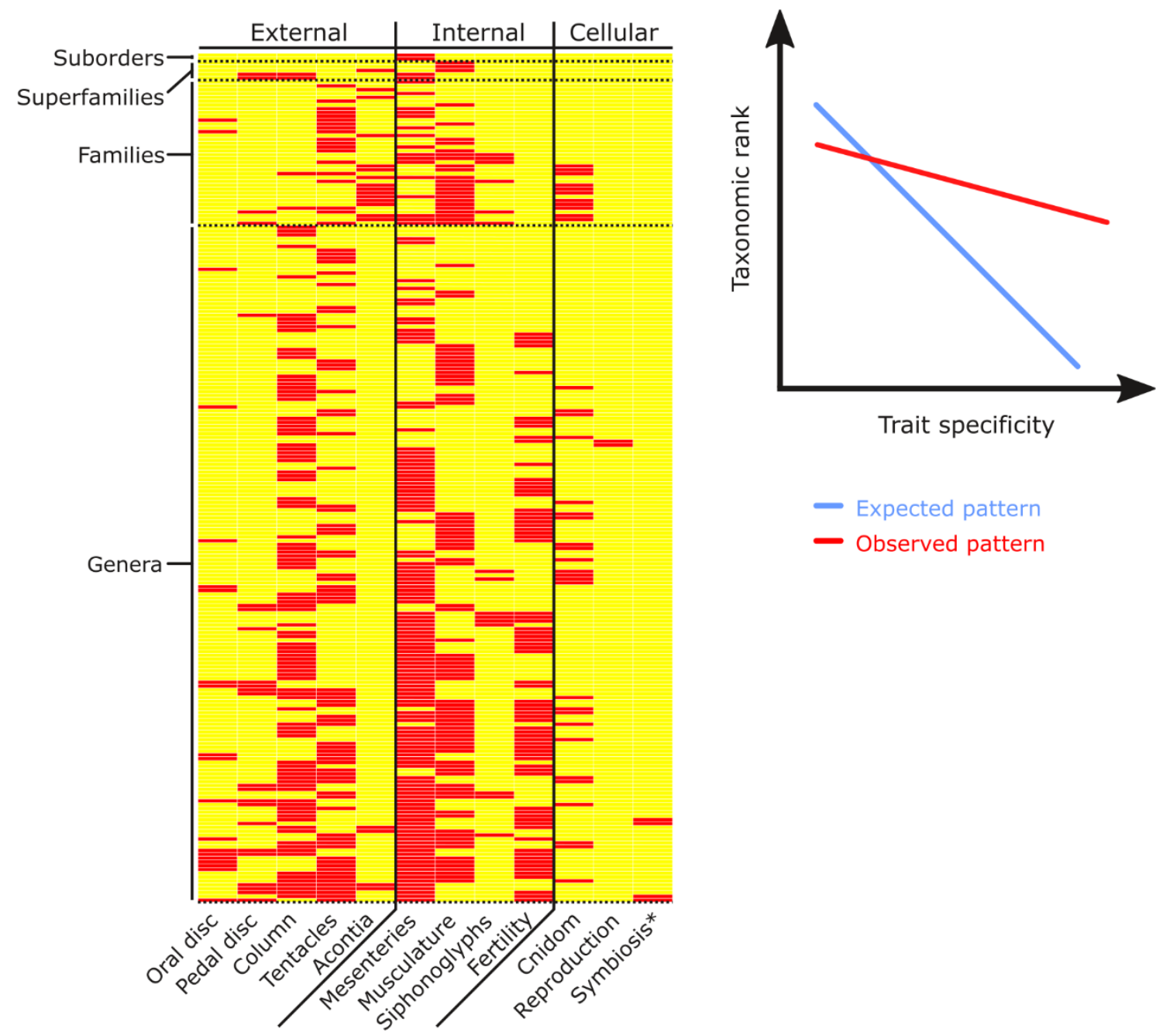

*Typically with hermit crabs, although the symbiosis with zooxanthellae is more frequent below the genus level.

Figure 3. Heat map showing the use of different diagnostic features for distinguishing actiniarian species. Yellow cells do not indicate that the character is absent but rather that is not determinant for identifying that particular taxon. The upper right plot illustrates the expected vs observed pattern of trait specificity against taxonomic rank. While it is expected that towards lower taxonomic ranks, the specificity of the trait increases (i.e. the differences become internal, cellular or taxon-specific; blue line), the relation in sea anemones is weakly proportional and heavily focused on the organization of the column and tentacles, and the internal arrangement of the mesenteries and muscles (red line).

Of all the characters mentioned above, none have been more profusely discussed within the scope of species delimitation than the cnidae. For some larger groups as the acontiate taxa within Metridioidea, nematocysts represent a fundamental feature in their systematics, therefore comments addressing the issue are recurrent in the literature (e.g. Fautin, 1988). 
The main problem has historically been related to the classification of these singular, microscopic characters. Several authors have proposed different, sometimes quite conflicting, nomenclatures to account for the vast amount of morphologies nematocysts may display (e.g. Schmidt, 1972; Mariscal, 1974; England, 1991; Östman, 2000). The form of the capsule, the characteristics of the tubule and the kind of spines are some examples of relevant features extracted from the nematocyst that determine to which type they belong (Mariscal, 1974; Reft and Daly, 2012). Nevertheless, even with a detailed map of the ultrastructure of the nematocyst, the translation from one nomenclature to another is not simple and thus, many species are currently described under different codes. On the other hand, it is still unclear how much of these variations actually contain a phylogenetic signal, which has been observed mostly among broader groups. For example, Rodríguez et al. (2014) confirmed that acontiate actiniarians possess a different type of $p$-rhabdoid with respect to other superfamilies like Actinoidea or Actinostoloidea. Towards more specific relationships, however, this pattern becomes blurry as some variations of the cnidae seems to be heavily influenced by physiological constraints, as has been previously suggested by Robson (1988) and Francis (2004).

\section{The multidisciplinary era of species delimitation}

The advent of molecular tools revolutionized ecological and evolutionary research, and with that, the task of delimiting species. Over the past 30 years, metrics of genetic distance have become a recurring approach to test species hypotheses where other lines of evidence alone seem to be insufficient. Differences in allele frequencies, for example, have been especially helpful to assess the species diversity in wide-spread genera, such as Actinia and Anthopleura. In some cases, this has led to the discovery of new species with otherwise, very contrasting life-history phenotypes (McFadden et al., 1997). Moreover, recent analyses have particularly been highlighting the role of geography in the genetic structure of anemone diversity (Larson and Daly, 2016; Daly et al., 2017). In fact, the distributional range, including habitat and ecologies, is thus far one of the best variables explaining the Actiniaria phylogeny across superfamily clades (Rodríguez et al., 2014). 
Most studies in sea anemones have addressed the delimitation issue from a population perspective, finding hidden cryptic diversity under a large spectrum of morphological varieties. This has typically been seen with allozymes markers (Solé-Cava and Thorpe, 1992; Monteiro et al., 1997; Manchenko et al., 2000; Schama et al., 2005); although analyses using high-throughput sequencing technologies have reached quite similar conclusions (Reitzel et al., 2013; Spano et al., 2018). Phylogenetic approaches using single or concatenated genes are less consistent, detecting both high and low levels of differentiation among closely related lineages (Acuña et al., 2007; Gomes et al., 2012; Pereira et al., 2014; Canales-Aguirre et al., 2015; González-Muñoz et al., 2015; Mallien et al., 2018). In terms of phylogenetic informativeness, the fragments12S rDNA and $18 \mathrm{~S}$ rDNA have proved to be more proficient to recover well-supported nodes compared to $16 \mathrm{~S}$ rDNA, 28S rDNA and other barcode markers, such as COI and ITS (Daly et al., 2010; Dohna and Kochzius, 2016). It is largely unknown how much of the disparities between phylogenies and morphological species are due to local processes of adaptation, however, insights on genome-wide data suggest that balancing selection might be recurrent among sea anemones (Reitzel et al., 2013).

Unlike morphology, only recently spatial distribution has begun to be explicitly included into species delimitation analyses. Nevertheless, results are encouraging as they have shown the benefits of doing so under an 'integrative taxonomy’ framework (Dayrat, 2005; Padial et al., 2010). Herrera and Shank (2016), for instance, compared different species hypotheses in a recalcitrant group of octocorals and found out that taxonomy-informed models that incorporate geographic and bathymetric variables tend to have stronger support than those based on genetic distance alone. Because sea anemones can be traced back to the early Cambrian (Han et al., 2010; Schwaiger et al., 2014), species relationships could be reasonably tested under predictions based both on historical as well as contemporaneous biogeographic patterns. For example, the diversification of sea anemones during the Mesozoic may help explain the odd absence of endemic families in the Southern Ocean (Rodríguez et al., 2007), or the existence of several bipolar genera (Rodríguez et al., 2009). The biggest challenge at this point is to distinguish between deep and shallow divergence processes, yet a recent study on the white-striped anemone (Anthothoe spp.) showed that, even with highly different populations, it is still quite possible to find traces of past distributions (Spano et al., 2018). 


\section{Conclusions and future perspectives}

The study about the nature and identity of sea anemones has come a long way since the times of Aristotle. Nowadays there are numerous, publicly available guidelines for the examination, analysis, and description of these strikingly polymorphic animals (e.g. Häussermann, 2004a; Spano and Flores, 2013; Angeli et al., 2016; Garese et al., 2016). Online databases such as 'Hexacorallians of the World' or 'Cnidabase' have also significantly contributed to the transmission of bibliographic and spatial information worldwide (Fautin, 2013; Garese and Acuña, 2016). Two species have even their genomes sequenced (Putnam et al., 2007; Baumgarten et al., 2015), and there is currently an ongoing project that seeks to expand these types of resources throughout Anthozoa (Quattrini et al., 2017). Overall, previous impediments related to the accessibility and dissemination of knowledge have gradually been replaced by deeper evolutionary questions about how divergent species really are or how likely it is that they hybridize with each other (e.g. Titus et al., 2018). Despite the complexity of the topic, new statistical methods are rising to the challenge of addressing these gaps. Approximate Bayesian computation models have become one of the most promising approaches, allowing to evaluate diverse hypotheses of how speciation might have occurred with differential levels of gene flow (review by Csilléry et al., 2010). Although little explored in anthozoans, recent studies are so far indicating that species may well originate either in sympatry or by secondary contact between welldifferentiated linages (Aurelle et al., 2017; Titus et al., 2018).

These methods are especially relevant now as spatial distribution seems to be the best predictor of species relationships (e.g. Larson and Daly, 2016). Regardless if they are based on concatenated genes or genome-wide data, geographic patterns are pervasive in anemone phylogenies and can remain unaltered even using different divergence parameters or proportions of missing data (e.g. Spano et al., 2018). Taxonomic assignments may greatly benefit from this conclusion since many descriptions are in need of revision. Moreover, it is estimated that we currently know about $70 \%$ of all existing actiniarian species, therefore it is expected that new taxa will keep appearing, especially towards the tropics where inventories are more incomplete (Fautin et al., 2013). Building future taxonomic analyses based on this well-stablished pattern would not only improve our understanding about sea anemones 
diversification but would also serve to define where to draw the line between more specific taxonomic groups.

It is noticeable from the present review that many factors are behind the recurring incongruence between morphology-based classifications and lower-level phylogenies; yet, there are still some missing pieces to complete the puzzle. It is especially important to know the role played by phenotypic plasticity and local adaptation in the morphological radiation of closely related linages (e.g. Mallien et al., 2018). In fact, compared to bilaterian animals, sea anemone populations exhibit very high differentiation values, even among individuals from close localities (e.g. Reitzel et al., 2013). The more genetic data arrives without a prior knowledge of characters structure and evolution, species delimitation studies will likely continue concluding that cryptogenic taxa are prevalent within Actiniaria. Given the case, candidate species would be better characterized as deep conspecific lineages, at least until additional data prove otherwise (de Queiroz, 2007; Padial et al., 2010). This rather conservative measure will help prevent taxonomic over splitting, thus easing the forthcoming task of assessing when genealogical units become differentiated beyond limits of reversibility.

\section{Acknowledgements}

We are very grateful to the doctoral program in Systematics and Biodiversity (Sistematica y Biodiversidad) from Universidad de Concepcion for discussions that contributed to the development of this paper. This work was supported by a CONICYT Doctoral Fellowship to C.A.S. The research of C.B.C.A. and V.H. was funded by FONDECYT \#1180897 and 1131039, respectively. D.G-U, S.S.M., and, C.B.C-A receive support from Nucleo Milenio INVASAL from Iniciativa Cientifica Milenio, Chile's Ministerio de Economia, Fomento y Turismo. 


\section{References}

Acuña, F.H., Excoffon, A.C., McKinstry, S.R., Martínez, D.E., 2007. Characterization of Aulactinia (Actiniaria: Actiniidae) species from Mar del Plata (Argentina) using morphological and molecular data. Hydrobiologia 592, 249-256.

Andres, A., 1884. Le Attinie. Verlag von Wilhelm Engelmann, Leipzig.

Angeli, A., Zara, F.J., Turra, A., Gorman, D., 2016. Towards a standard measure of sea anemone size: assessing the accuracy and precision of morphological measures for cantilever-like animals. Marine Ecology $37,1019-1026$.

Arellano, S.M., Fautin, D.G., 2001. Redescription and range extension of the sea anemone Exocoelactis actinostoloides (Wassilieff, 1908), with revision of genus Exocoelactis (Cnidaria, Anthozoa, Actiniaria). Zoosystema 23, 645-658.

Aurelle, D., Pivotto, I.D., Malfant, M., Topçu, N.E., Masmoudi, M.B., Chaoui, L., Kara, H.M., Coelho, M.A.G., Castilho, R., Haguenauer, A., 2017. Fuzzy species limits in Mediterranean gorgonians (Cnidaria, Octocorallia): inferences on speciation processes. Zoologica Scripta.

Ayre, D.J., Grosberg, R.K., 1995. Aggression, habituation, and clonal coexistence in the sea anemone Anthopleura elegantissima. American Naturalist 146, 427-453.

Baumgarten, S., Simakov, O., Esherick, L.Y., Liew, Y.J., Lehnert, E.M., Michell, C.T., Li, Y., Hambleton, E.A., Guse, A., Oates, M.E., Gough, J., Weis, V.M., Aranda, M., Pringle, J.R., Voolstra, C.R., 2015. The genome of Aiptasia, a sea anemone model for coral symbiosis. Proceedings of the National Academy of Sciences 112, 11893-11898.

Bigger, C.H., 1980. Interspecific and intraspecific acrorhagial aggressive behavior among sea anemones: a recognition of self and not-self. Biological Bulletin 159, 117-134.

Canales-Aguirre, C.B., Quiñones, A., Hernández, C.E., Neill, P.E., Brante, A., 2015. Population genetics of the invasive cryptogenic anemone, Anemonia alicemartinae, along the southeastern Pacific coast. Journal of Sea Research 102, 1-9.

Carlgren, O., 1949. A survey of the Ptychodactiaria, Corallimorpharia and Actiniaria. Kungliga Svenska Vetenskapsakademiens Handlingar 1, 1-121.

Csilléry, K., Blum, M.G.B., Gaggiotti, O., François, O., 2010. Approximate Bayesian computation (ABC) in practice. Trends in Ecology \& Evolution 25, 410-418.

Cuvier, G., 1817. Le Règne Animal. Déterville, Paris.

Daly, M., Crowley, L.M., Larson, P., Rodríguez, E., Heestand Saucier, E., Fautin, D.G., 2017. Anthopleura and the phylogeny of Actinioidea (Cnidaria: Anthozoa: Actiniaria). Organisms Diversity \& Evolution 17, 545-564.

Daly, M., Chaudhuri, A., Gusmão, L.C., Rodríguez, E., 2008. Phylogenetic relationships among sea anemones (Cnidaria: Anthozoa: Actiniaria). Molecular Phylogenetics and Evolution 48, 292-301.

Daly, M., Endara, L.A., Burleigh, J.G., 2015. Peeking behind the page: using natural language processing to identify and explore the characters used to classify sea anemones. Zoologischer Anzeiger 256, 54-60. 
Daly, M., Gusmão, L.C., Reft, A.J., Rodríguez, E., 2010. Phylogenetic signal in mitochondrial and nuclear markers in sea anemones (Cnidaria, Actiniaria). Integrative and Comparative Biology 50, 371-388.

Dana, J.D., 1846. Structure and Classification of Zoophytes Lea and Blanchard, Philadelphia.

Dayrat, B., 2005. Towards integrative taxonomy. Biological Journal of the Linnean Society 85, 407-415.

de Queiroz, K., 2007. Species concepts and species delimitation. Systematic Biology 56, 879-886.

Dohna, T.A., Kochzius, M., 2016. Obstacles to molecular species identification in sea anemones (Hexacorallia: Actiniaria) with COI, a COI intron, and ITS II. Marine Biodiversity 46, 291-297.

Edmands, S., Fautin, D.G., 1991. Redescription of Aulactinia veratra n. comb. (=Cnidopus veratra) (Coelenterata: Actiniaria) from Australia. Records of the Western Australian Museum 15, 59-68.

Ehrenberg, C.G., 1834. Beiträge zur physiologischen Kenntniss der Corallenthiere im allgemeinen, und besonders des Rothen Meeres, nebst einem Versuche zur physiologischen Systematik derselben. Abhandlungen der Königlichen Akademie der Wissenschaften zu Berlin, 225-380.

England, K.W., 1987. Certain Actiniaria (Cnidaria, Anthozoa) from the Red Sea and tropical Indo-Pacific Ocean. Bulletin of the British Museum (Natural History) 53, 205-292.

England, K.W., 1991. Nematocysts of sea anemones (Actiniaria, Ceriantharia and Corallimorpharia: Cnidaria): nomenclature. Hydrobiologia 216, 691-697.

Fautin, D.G., 1988. Importance of nematocysts to actinian taxonomy. In: Lenhoff, H.M. (Ed.), The Biology of Nematocysts. Academic Press, San Diego, pp. 487-500.

Fautin, D.G., 2013. Hexacorallians of the World.

Fautin, D.G., 2016. Catalog to families, genera, and species of orders Actiniaria and Corallimorpharia (Cnidaria: Anthozoa). Zootaxa 4145, 449.

Fautin, D.G., Malarky, L., Soberón, J., 2013. Latitudinal diversity of sea anemones (Cnidaria: Actiniaria). The Biological Bulletin 224, 89-98.

Francis, L., 1973. Intraspecific aggression and its effect on the distribution of Anthopleura elegantissima and some related sea anemones. The Biological Bulletin 144, 73-92.

Francis, L., 2004. Microscaling: why larger anemones have longer cnidae. The Biological Bulletin 207, 116129.

Frey, H., Leuckart, R., 1847. Beiträge zur kenntniss wirbelloser thiere mit besonderer berücksichtigung der fauna des norddeutschen meeres. Friedrich Vieweg \& Sohn, Braunschweig.

Garese, A., Acuña, F.H., 2016. Cnidabase: Database of the cnidae of sea anemones and corallimorpharians. http://labic.mdp.edu.ar/cnidabase/.

Garese, A., Carrizo, S., Acuña, F.H., 2016. Biometry of sea anemone and corallimorpharian cnidae: statistical distribution and suitable tools for analysis. Zoomorphology 135, 395-404.

Gomes, P.B., Schama, R., Sole-Cava, A.M., 2012. Molecular and morphological evidence that Phymactis papillosa from Argentina is, in fact, a new species of the genus Bunodosoma (Cnidaria: Actiniidae). Journal of the Marine Biological Association of the United Kingdom 92, 895-910. 
González-Muñoz, R., Simões, N., Mascaró, M., Tello-Musi, J.L., Brugler, M.R., Rodríguez, E., 2015. Morphological and molecular variability of the sea anemone Phymanthus crucifer (Cnidaria, Anthozoa, Actiniaria, Actinoidea). Journal of the Marine Biological Association of the United Kingdom 95, 69-79.

Gosse, P.H., 1860. A History of the British Sea-Anemones and Corals. Van Voorst, London.

Gusmão, L.C., Grajales, A., Rodríguez, E., 2018. Sea anemones through X-rays: visualization of two species of Diadumene (Cnidaria, Actiniaria) using micro-CT. American Museum Novitates, 1-45.

Haeckel, E., 1879. Das System der Medusen. Gustav Fisher, Jena.

Han, J., Kubota, S., Uchida, H., Stanley, G.D.J., Yao, X., Shu, D., Li, Y., Yasui, K., 2010. Tiny sea anemone from the lower Cambrian of China. PLoS ONE 5, e13276.

Hart, C.E., Crowe, J.H., 1977. The effect of attached gravel on survival of intertidal anemones. Transactions of the American Microscopical Society 96, 28-41.

Hatschek, B., 1888. Lehrbuch der Zoologie: eine morphologische Übersicht des Thierreiches zur Einführung in das Studium dieser Wissenschaft. Gustav Fischer, Jena.

Häussermann, V., 2004a. Identification and taxonomy of soft-bodied hexacorals exemplified by Chilean sea anemones; including guidelines for sampling, preservation and examination. Journal of the Marine Biological Association of the United Kingdom 84, 931-936.

Häussermann, V., 2004b. Redescription of Phymactis papillosa (Lesson, 1830) and Phymanthea pluvia (Drayton in Dana, 1846)(Cnidaria: Anthozoa), two actiniid sea anemones from the south east Pacific with a discussion of the genera Phymactis, Bunodosoma and Phymanthea. Zoologische Mededelingen 78, $345-381$.

Herrera, S., Shank, T.M., 2016. RAD sequencing enables unprecedented phylogenetic resolution and objective species delimitation in recalcitrant divergent taxa. Molecular Phylogenetics and Evolution 100, 7079.

Hertwig, R., 1882. Report on the Actiniaria dredged by H.M.S. Challenger during the years 1873-1876. Report on the Scientific Results of the Voyage of the H.M.S. Challenger during the years 1873-76 (Zoology) $6,1-136$.

Hughes, R.N., 1987. The functional ecology of clonal animals. Functional Ecology 1, 63-69.

Lamarck, J.B.P., 1801. Système des Animaux Sans Vertèbres. Deterville, Paris.

Larson, P.G., Daly, M., 2016. Phylogenetic analysis reveals an evolutionary transition from internal to external brooding in Epiactis Verrill (Cnidaria: Anthozoa: Actiniaria) and rejects the validity of the genus Cnidopus Carlgren. Molecular Phylogenetics and Evolution 94 (B), 548-558.

Layden, M.J., Rentzsch, F., Röttinger, E., 2016. The rise of the starlet sea anemone Nematostella vectensis as a model system to investigate development and regeneration. Wiley Interdisciplinary Reviews.

Developmental Biology 5, 408-428.

Mallien, C., Porro, B., Zamoum, T., Olivier, C., Wiedenmann, J., Furla, P., Forcioli, D., 2018. Conspicuous morphological differentiation without speciation in Anemonia viridis (Cnidaria, Actiniaria). Systematics and Biodiversity 16, 271-286.

Manchenko, G.P., Dautova, T.N., Latypov, Y.Y., 2000. High level of genetic divergence between sympatric color morphs of the littoral sea anemone Anthopleura orientalis (Anthozoa: Actiniaria). Biochemical Systematics and Ecology 28, 737-750. 
Mariscal, R.N., 1974. Nematocysts. In: Muscatine, L., Lenhoff, H.M. (Eds.), Coelenterate Biology: Reviews and New Perspectives. Academic Press, New York, pp. 129-178.

McFadden, S.C., Grosberg, K.R., Cameron, B.B., Karlton, P.D., Secord, D., 1997. Genetic relationships within and between clonal and solitary forms of the sea anemone Anthopleura elegantissima revisited: evidence for the existence of two species. Marine Biology 128, 127-139.

Milne-Edwards, H., Haime, J., 1857. Histoire naturelle des Coralliaires ou Polypes proprement dits. Librairie encyclopédique de Roret, Paris.

Monteiro, A.F., Sole-Cava, M.A., Thorpe, P.J., 1997. Extensive genetic divergence between populations of the common intertidal sea anemone Actinia equina from Britain, the Mediterranean and the Cape Verde Islands. Marine Biology 129, 425-433.

Östman, C., 2000. A guideline to nematocyst nomenclature and classification, and some notes on the systematic value of nematocysts. Scientia Marina 64, 31-46.

Padial, J.M., Miralles, A., De la Riva, I., Vences, M., 2010. The integrative future of taxonomy. Frontiers in Zoology 7, 1-14.

Pereira, A.M., Brito, C., Sanches, J., Sousa-Santos, C., Robalo, J.I., 2014. Absence of consistent genetic differentiation among several morphs of Actinia (Actiniaria: Actiniidae) occurring in the Portuguese coast. Zootaxa 3893, 595-600.

Putnam, N.H., Srivastava, M., Hellsten, U., Dirks, B., Chapman, J., Salamov, A., Terry, A., Shapiro, H., Lindquist, E., Kapitonov, V.V., 2007. Sea anemone genome reveals ancestral eumetazoan gene repertoire and genomic organization. Science 317, 86-94.

Quattrini, A., Faircloth, B.C., Duenas, L., Bridge, T., Brugler, M.R., Calixto-Botia, I., DeLeo, D., Foret, S., Herrera, S., Lee, S., Miller, D.J., Prada, C., Radis-Baptista, G., Ramirez-Portilla, C., Sanchez, J., Rodriguez, E., McFadden, C., 2017. Universal target-enrichment baits for anthozoan (Cnidaria) phylogenomics: new approaches to long-standing problems. Molecular Ecology Resources.

Reft, A.J., Daly, M., 2012. Morphology, distribution, and evolution of apical structure of nematocysts in Hexacorallia. Journal of Morphology 273, 121-136.

Reitzel, A.M., Herrera, S., Layden, M.J., Martindale, M.Q., Shank, T.M., 2013. Going where traditional markers have not gone before: utility of and promise for RAD sequencing in marine invertebrate phylogeography and population genomics. Molecular Ecology 22, 2953-2970.

Robson, E.A., 1988. Problems of supply and demand for cnidae in Anthozoa. In: Lenhoff, H.M. (Ed.), The Biology of Nematocysts. Academic Press, San Diego, pp. 179-207.

Rodríguez, E., Barbeitos, M.S., Brugler, M.R., Crowley, L.M., Grajales, A., Gusmão, L.C., Häussermann, V., Reft, A.J., Daly, M., 2014. Hidden among sea anemones: The first comprehensive phylogenetic reconstruction of the order Actiniaria (Cnidaria, Anthozoa, Hexacorallia) reveals a novel group of hexacorals. PLoS Biology 9, e96998.

Rodríguez, E., Barbeitos, M.S., Daly, M., Gusmão, L.C., Häussermann, V., 2012. Toward a natural classification: phylogeny of acontiate sea anemones (Cnidaria, Anthozoa, Actiniaria). Cladistics 28, 375-392.

Rodríguez, E., López-González, P.J., 2008. The gastropod-symbiotic sea anemone genus Isosicyonis Carlgren, 1927 (Actiniaria: Actiniidae): a new species from the Weddell Sea (Antarctica) that clarifies the taxonomic position of the genus. Scientia Marina 72, 73-86. 
Rodríguez, E., López-González, P.J., Daly, M., 2009. New family of sea anemones (Actiniaria, Acontiaria) from deep polar seas. Polar Biology 32, 703-717.

Rodríguez, E., López-González, P.J., Gili, J.M., 2007. Biogeography of Antarctic sea anemones (Anthozoa, Actiniaria): what do they tell us about the origin of the Antarctic benthic fauna? Deep Sea Research Part II: Topical Studies in Oceanography 54, 1876-1904.

Schama, R., Sole-Cava, A.M., Thorpe, J.P., 2005. Genetic divergence between east and west Atlantic populations of Actinia spp. sea anemones (Cnidaria: Actiniidae). Marine Biology 146, 435-443.

Schlesinger, A., Kramarsky-Winter, E., Rosenfeld, H., Armoza-Zvoloni, R., Loya, Y., 2010. Sexual plasticity and self-fertilization in the sea anemone Aiptasia diaphana. PLoS ONE 5, e11874.

Schmidt, H., 1972. Die Nesselkapseln der Anthozoen und ihre Bedeutung fur die phylogenetische Systematik. Helgoländer Wissenschaftliche Meeresuntersuchungen 23, 422-458.

Schwaiger, M., Schönauer, A., Rendeiro, A.F., Pribitzer, C., Schauer, A., Gilles, A.F., Schinko, J.B., Renfer, E., Fredman, D., Technau, U., 2014. Evolutionary conservation of the eumetazoan gene regulatory landscape. Genome Research 24, 639-650.

Sebens, K.P., Paine, R.T., 1979. Biogeography of anthozoans along the west coast of South America: habitat, disturbance, and prey availability. Proceedings of the International Symposium of Marine Biogeography and Evolution in the Southern Hemisphere. N. Z. D. S. I. R., Auckland, New Zealand, pp. 219-237.

Solé-Cava, A.M., Thorpe, J.P., 1992. Genetic divergence between colour morphs in populations of the common intertidal sea anemones Actinia equina and A. prasina (Anthozoa: Actiniaria) in the Isle of Man. Marine Biology 112, 243-252.

Spano, C.A., Flores, V., 2013. Staining protocol for the histological study of sea anemones (Anthozoa: Actiniaria) with recommendations for anesthesia and fixation of specimens. Latin American Journal of Aquatic Research 41, 1019-1024.

Spano, C.A., Häussermann, V., Acuña, F.H., Griffiths, C., Seeb, L.W., Gomez-Uchida, D., 2018. Hierarchical biogeographical processes largely explain the genomic divergence pattern in a species complex of sea anemones (Metridioidea: Sagartiidae: Anthothoe). Molecular Phylogenetics and Evolution 127, 217-228.

Spano, C.A., Rozbaczylo, N., Häussermann, V., Bravo, R., 2013. Redescription of the sea anemones Anthopleura hermaphroditica and Bunodactis hermafroditica (Cnidaria: Anthozoa: Actiniaria) from Chile. Revista de Biología Marina y Oceanografía 48, 521-534.

Stephenson, T.A., 1921. On the classification of Actiniaria. Part II. - Consideration of the whole group and its relationships, with special reference to forms not treated in Part I. Quarterly Journal of Microscopical Science $65,493-576$.

Stephenson, T.A., 1935. The British Sea Anemones. The Ray Society, London.

Stoletzki, N., Schierwater, B., 2005. Genetic and color morph differentiation in the Caribbean sea anemone Condylactis gigantea. Marine Biology 147, 747-754.

Titus, B.M., Blischak, P.D., Daly, M., 2018. Genomic signatures of sympatric speciation with historical and contemporary gene flow in a tropical anthozoan. bioRxiv, 399360.

Verrill, A.E., 1864. Revision of the Polypi of the eastern coast of the United States. Memoirs of the Boston Society of Natural History 1, 1-45. 
Weill, R., 1934. Contribution a l'Étude des Cnidaires et de leurs Nématocystes. Les Presses Universitaires de France, Paris.

Williams, R.B., 1973. Are there physiological races of the sea anemone Diadumene luciae? Marine Biology 21, 327-330. 